\title{
Discussion on the Reform of the "North Hankou" International Commodity Exhibition and Trading Center in Wuhan, Hubei Province and Circulation Mode
}

\author{
Xiaojun Zhang \\ Modern Service Trade Research Center \\ Wuhan Technology and Business University \\ Wuhan, China
}

\begin{abstract}
As a new mode of trade circulation industry in Wuhan, "North Hankou" is not only a rising growth pole of regional economic development, but also a special area for the development of Wuhan's open economy. Therefore, it is helpful for Wuhan to build an international trade city and promote Hubei province to take the lead in the rise of the central region. In this paper, the significance, effect and corresponding countermeasures are analyzed based on the development goals of the construction of Wuhan "North Hankou" international commodity exhibition center, trading center, distribution center and the largest inland trade and investment expo center.
\end{abstract}

Keywords-Wuhan; "North Hankou"; import commodities; circulation mode; internationalization

\section{INTRODUCTION}

Throughout the history of China, Wuhan has become a bright business card in the interior of China because of its unique geographical conditions and advantages of trade circulation industry. "North Hankou", as the growth pole and expansion zone of the development of modern trade industry in Wuhan, should also be the epitome of Hubei's undertaking of the eastern industrial transfer and the reform of the traditional trade circulation mode.

"North Hankou" International Commodity Trading Center is located in the "Golden Triangle" zone between Wuhan Tianhe International Airport, North Wuhan Railway Marshalling Yard and Wuhan Changjiang Xingang, so it is positioned as big Wuhan's Pudong. In the course of Wuhan becoming an international window for opening up and linking the world, as a trade platform with a favorable policy, convenience and access to the world, the North Hankou International Commodity Exhibition and Trading Center is like the pearl in this window and the flagship in the commercial sea.

\section{ThE NeCESSITY AND PRACTICAL SIGNIFICANCE}

Wuhan is located in the Central Plains. In the framework of the big city, many people and resources are collected. Moreover, its transportation is convenient, and railway, highway, water transportation and aviation are all round, so it is one of the hub cities in the country. The establishment of "North Hankou" International Commodity Exhibition and Trading Center coincides with the time. However, since the establishment of the "North Hankou", it has a deep influence on the traditional business model, and its development pace is not fast, and its due advantages are far from being brought into play. The main reasons are as follows:

"North Hankou" lacks new business format. By the end of 2013, "North Hankou" had started to build 9 professional markets, including 6 markets for business operation, 2 building material industrial parks, 2 logistics parks and 5 large municipal facilities. "North Hankou" has a good momentum of development, but it also faces fierce competition in the market upgrading of Yiwu and Wenzhou. There is no way out for the simple copy of Hanzheng Street model, so "North Hankou" must carry out the upgrading and transformation of the business format, closely combine with the virtual market, the modern capital market and the overseas market, and establish a new comprehensive development format with the integration of international cohesiveness in circulation, manufacturing, storage and finance.

- "North Hankou" lacks international famous brands. It has international brands such as Playboy men's flagship stores, but it is troubled by imitated brands and the actions of pushing the boundaries. There are a large number of international brand individual business models, and the proportion of the franchiser and direct store in the form of mom-and-pop is 9:1. Meanwhile, franchisees are short of long-term plans with extensive management, resulting in larger losses. Compared with the famous "Canton Fair" and "Small commodity oceans, Shoppers paradise" in Zhejiang Yiwu International Trade City, the North Hankou International Commodity Trading Center enjoys a low popularity. It is still in its growth stage, and it has not yet become a card for China's inland market. Therefore, the lack of international commodity 
brands is an important obstacle to the internationalization of "North Hankou".

- "North Hankou" lacks the leading position in the midwest market. If the Yangtze River economic belt is likened to a giant dragon, Hubei is the waist of the dragon, so it plays an important supporting role in the development of the Yangtze River economic belt. At present, cities along the upper and lower reaches of the Yangtze River economic belt such as Shanghai, Chongqing and Ningbo, as well as Hunan, Changsha, Hefei and other large cities in the central region, have set up high-standard trade centers such as "International Commodity Exhibition and Trading Center" and "Pilot Zone of Cross-border E-commerce Service" in the comprehensive bonded zone. Taking Chongqing Bonded Commodity Exhibition and Trading Center as an example, the import price of foreign wine, sunglasses, kitchenware and fresh food in the trading center is $20 \%-30 \%$ lower than the market price. In the central and western regions, "North Hankou" has no obvious competitive advantage and leading position.

- "North Hankou" lacks commercial channels to integrate with the international market. The professional market group of " North Hankou" includes international wholesale city, international famous shop street and colorful MINI mall with the word "international", but it does not connect with the real consumer groups at home and abroad, and the channels are not smooth. "North Hankou" International Commodity Trading Center is defined as the fourth generation new wholesale market, it is the key support project of the Ministry of Finance and the Ministry of Commerce, but it is deeply affected by the traditional business model. At present, in addition to the gradual expansion of local consumer groups in Wuhan, there are about 6,000 foreignfunded enterprises, and more than 1,500 economic and technical experts work in Wuhan each year. The proportion of expatriates who live in Wuhan for a long time is $0.5 \%$, reaching nearly 10,000 people. In the next few years, nearly 50 countries will be set up consulates in Wuhan, and Wuhan will be the R \& D center and the headquarters center of a large number of multinational companies. More overseas people will come to Wuhan to start a business and live there. Their meals, accommodation, travel, shopping and entertainment will form a huge consumer group. Wuhan's international trade services will be indispensable, but due to the lack of commercial channels, "North Hankou" cannot make the best use of its functions.

These constraints make "North Hankou" a bottleneck for the development and reform of Wuhan's modern trade business, and its advantages are far from being realized.

\section{THE EFFECT ANALYSIS}

"North Hankou" International Commodity Exhibition and Trading Center (hereinafter referred to as the center) draws lessons from the advanced ideas of the international and domestic large trade markets, attaches importance to import trade, improves the circulation system and builds the idea of specialized, fashionable, branded, modernized and internationalized trading center in the inland area. Moreover, it has attracted the attention and esteem of Hubei's import and export enterprises. The establishment of the center is aimed at changing the influence of traditional trade and circulation mode on "North Hankou", and realizing the main carrier of "business flow-Logistics-capital flow- information flow", so its effect cannot be underestimated.

- It is conducive to changing the unsound situation of "North Hankou" import commodity market. The center should expand trade and build four service systems, such as electricity, finance, logistics and warehousing, and strive to build world-class business logistics platform, invite a large number of buyers from all over the country and even the world to come here to purchase so as to form a large-scale procurement center, give full play to the advantages of low cost, developed Internet business and stable customers to expand foreign trade business for "North Hankou", and build three major functional platforms for Hubei province's import and export demonstration base: The first to build a global international commodity exhibition and trading center platform with "genuine goods at a fair price"; The second is to set up a trading platform for the combination of inland trade and trade in services. The third is to build international trade information public service platform.

- It is conducive to boosting the facilitation of Wuhan's international trade. At present, Wuhan is actively docking the coastal free trade area and carrying out the declaration work of the pilot work in the inland free trade area. The establishment of the "North Hankou" International Commodity Exhibition and Trading Center is the main promoter of Wuhan's FTA which can break the previous policy restrictions, and the bottleneck of internal introduction and external links in cross-border trade, promote the capital flow, information flow, business flow, logistics and other innovative elements from a higher level and wider area to "North Hankou", develop the headquarters economy through the market, allow the Wuhan people to participate in the reform of international trade facilitation at home and share the "feast" brought about by the reform.

- It is conducive to giving full play to the unique geographical advantages of Wuhan. Wuhan is an important node linking the "Yangtze River Economic Belt", "Maritime Silk Road" and "Land Silk Road". Such advantages are unique throughout the country. The center is located in the golden node of strategic resources of the three major transportation hubs, such as aviation, railway and port, which are unique to Wuhan. Moreover, it is surrounded by Wuhan Aviation City, Hengdian Marshalling Yard and Yangluo Deepwater Port. The center give full play to 
the advantages of Wuhan's convenient transportation and integrate entity management, network sales and modern logistics system into one, build the largest import commodity exhibition center and cross-border e-commerce marketing center in central China, comply with the increasing consumption demand of residents in order to make everything in Southeast Asia, Africa and South America can be wholesale here, and create a large platform for domestic operators and consumers to experience products with high quality and low cost from all over the world without going abroad.

- It is conducive to tapping the potential of Wuhan's foreign trade operators. In the background of the low developed foreign economies and the upgrading of domestic economy to consumption, we should integrate and utilize the market resources of foreign trade entities in Wuhan, import foreign milk, red wine, coffee and olive oil and other bulk commodities selectively in batches, give full play to the expertise of foreign trade operators in international trade, strengthen the coordinated development of domestic trade and foreign trade, take trade as support, take logistics as the carrier, integrate into the consumer area, open the "skylight" of import commodity trading marketing, and radiate the central role to Europe and the United States and the Asia Pacific region.

- It is conducive to enjoying the series of policies that the State supports the rise of central China. In recent years, the national strategies have been concentrated in Wuhan in terms of the strategy of "the rise of central China ", the strategy of the central city of the central region, and the strategy of the Yangtze Economic Belt, etc. "Stabilizing exports, expanding imports and reducing favorable balance" have been identified as the overall plan for the development of foreign trade. With the course adjustment of China's trade policy, a more large-scale import has been given a new mission. The establishment of the North Hankou International Commodity Exhibition and Trading Center will actively connect the country with the strategic orientation of encouraging the expansion of imports, thus winning the dividends from the interaction of the economic elements, such as funds, commodities, information and labor in the Wuhan city circle.

\section{OBJECTIVES AND SUGGESTIONS}

"North Hankou" not only belongs to the big Wuhan and Hubei, but also belongs to the Yangtze River economic belt and even China. The establishment of the "North Hankou" International Commodity Exhibition and Trading Center is a new breakthrough. Therefore, it will play a positive role in seizing the strategic opportunity of" The Belt and Road" in Hubei, promoting the great opening up and promoting the great transformation and speeding up the construction of the inland open economic highland. The specific contents should include "five centers" and "five big promotions", and provide protection for policy promotion and implementation measures.

- Build the largest international commodity exhibition and trading center in the province, and enlarge and strengthen Hubei's trade circulation scale

- Compared with the developed coastal areas, due to the slow transformation of the business mechanism and the heavy historical burden of enterprises, Wuhan's large-scale trade and wholesale enterprises and specialized markets are relatively backward and limited in scale. Therefore, we should rely on the existing commercial resources of "Hankou North" and the popularity of Wuhan, strengthen the exhibition and display function of the center, optimize the display and layout, enrich the display varieties, innovate the display mode, and build the largest and most influential annual exhibition platform for imported goods in Hubei province in order to create the scale and influence of Hubei's commerce and circulation industry in terms of government efficiency, service standards, rule of law environment, social credit environment and policy of attracting foreign investment.

- Create a region-based international commodity exhibition and trading center, and enhance the radiating power of Hubei's trade circulation industry

- The core of the construction of the international commodity trading center is to realize the modernization, high-end and centralization of Hubei's trade circulation, become the breakthrough point and growth point of the innovation of Hubei's trade circulation mode, promote the coordinated development of the large state-owned, private and foreign retail industry in Hubei and accelerate the formation of the modernized pattern of trade and trade circulation by strengthening the linkage of import and export transactions. When implementing the "promoting trade with the exhibition", we should give full play to and expand the trade function of the regional import commodities in the center, promote the expansion of the "North Hankou" market, expand to the second-level and third-level markets and the coastal market, and build a regional trading platform with strong radiation, promote international trade cooperation, improve the level of import development and optimize the trade circulation industry in Hubei, and provide a good foundation for the development of commercial resources.

- Build a national test platform for cross-border ecommerce, and implement the development mode of Internet plus trade

- By taking the pilot of cross-border trade e-commerce services as an opportunity and the Wuhan bonded zone and trading center as a base, we should try the relevant policies first, implement the $\mathrm{O} 2 \mathrm{O}$ development mode, and build an import cross-border e-commerce experiment platform. At the same time, 
relying on the international e-commerce application platform of Hubei Province, we can not only make foreign trade more convenient and more efficient, but also expand to individual consumers, thus making "Haitao" more secure and more convenient for import trade.

- Build the largest import commodity distribution center in the Inland, and realize the model of " facilitation, diversification and specialization" in trade

- We should actively cultivate and rely on the economic development of the Wuhan city circle, seize the opportunity for Wuhan to apply for pilot work in the free trade area, create an exhibition platform for import commodities, including "display, trading and information", actively encourage small and medium-sized business circulation enterprises to participate in the construction of the "Hankou North" International Commodity Exhibition and Trading Center through a variety of ways, such as equity participation, contract, merger, acquisition, chain, trusteeship and franchise, make the "Hankou North" a center for import and export commodities, the inland distribution center of imported goods and the export and transfer center of inland commodities to the Eurasian region so as to become a model with "convenient trade environment, diversified trade functions and specialized trade services" in the innovation of circulation mode.

- The largest inland trade and investment expo center, and form a win-win mechanism between industries and enterprises.

- We should pay attention to and promote the construction of the international commodity exhibition and trading center, build a complete commercial enterprise credit system for "Hankou North", standardize the order of business operation, optimize the environment of commercial legal system, and guide the improvement of the cooperation relationship between the internal and foreign trade enterprises and the production enterprises. The construction of the center will highlight transaction, internationalization, guidance and interaction, take the industry transfer and investment and trade promotion as the main line, take information exchange, exhibition and display, project promotion, cooperation and negotiation and special forum as the main contents, build a platform for economic and technological exchanges and cooperation between Chinese and foreign businessmen, promote the comprehensive docking of Wuhan with domestic and foreign markets, capital and resources, carry out the mutual benefit and win-win strategy, form a good development mechanism for the circulation industry, and make economic contributions to create a new situation for the development of Hubei's trade circulation enterprises.

\section{CONCLUSION}

In the future, the "North Hankou" International Commodity Exhibition and Trading Center will set up and run more than 10 foreign-related public service platforms, achieve the joining of 500-1,000 foreign trade enterprises, offer 50000-100000 jobs, achieve the goal of more than US $\$ 100$ billion in output value, and realize the largest inland trading platform with diversified circulation functions, transaction network, brand management and internationalization. As China's economy is coming into the "13th Five-Year" period, "North Hankou" is in the process of achieving a qualitative leap from the accumulation of quantity. In the key period of realizing the leapfrog development, the construction of the international commodity exhibition and trading center has made "North Hankou" take a soaring wing and soar freely in the innovative business circulation mode.

\section{REFERENCES}

[1] Xiong Jie. Strategic Thinking on the Development of "North Hankou" Business Logistics Hub Area [J], Logistics Technology, 2014, (01).

[2] Wu Hao. Zall Makes Full Effort to Build a Domestic Demand Trading Platform Cluster [N], Changjiang Daily, 2013-06-28.

[3] Hu Siyong. The Opening of "North Hankou" First Wholesale City Creates a New Business Height in Wuhan [N], Hubei Daily, 2009-1231.

[4] Yang Guanghua. The Foundation of the "North Hankou" International Commodity Trading Center [N], Changjiang Daily, 2007-11-12.

[5] Yue Qiaohong Zhang Jiahua. Experience for the Development of Port Logistics at Home and Abroad [J]. Hubei Daily, 2009-05-06. 